\title{
Promoting Bike Helmet Safety for Urban Children Through a Culturally Tailored Educational Video Intervention
}

\author{
Leticia Manning Ryan, MD, $\mathrm{MPH}^{1}$ \\ Barry S. Solomon, MD, MPH ${ }^{1}$ \\ Susan Ziegfeld, MSN, PNP-BC ${ }^{2}$ \\ Andrea Gielen, ScD, $\mathrm{ScM}^{3}$ \\ Lauren Malloy, LMSW, MSW ${ }^{2}$ \\ Daniel Foster, DO, $\mathrm{MPH}^{3}$ \\ Katherine Clegg Smith, $\mathrm{PhD}^{3}$ \\ Eileen McDonald, $\mathrm{MS}^{3}$
}

\begin{abstract}
Bicycle-related falls are a significant cause of mortality and morbidity. Use of bicycle helmets substantially reduces risk of severe traumatic brain injury but compliance with this safety practice is particularly low in urban children. We recruited eleven 8- to 15-year-old youth to participate in focus groups to inform the creation of a video promoting helmet use. Key emerging themes included that youth were responsible for keeping themselves safe and that most youth had cell phones with cases to protect them. A video was created that linked the concept of use of cases to protect phones to use of helmets to protect heads. Soliciting information from urban youth was helpful for developing this educational video.
\end{abstract}

Keywords: injury prevention; safety; unintentional injury; injury prevention; safety; child/ adolescent health; health education

\section{ASSESSMENT OF NEED}

Bicycle-related falls are a significant cause of mortality and morbidity. Urban youth in the 10- to 15-year age-group are at high risk for fatal injury (U.S. Department of Transportation National Highway Traffic

Health Promotion Practice

March 2019 Vol. 20, No. (2) 157-159

DOI: $10.1177 / 1524839918822271$

Article reuse guidelines: sagepub.com/journals-permissions (c) 2019 Society for Public Health Education
Safety Administration, 2013). Use of helmets is a proven intervention that reduces bicycle-related head injury (Thompson, Rivara, \& Thompson, 1999). Despite this, less than half of U.S. children wear helmets when riding bicycles and use is lower among older children, minorities, and those insured by Medicaid (Sullins, Yaghoubian, Nguyen, Kaji, \& Lee, 2014).

Prevention programs prioritizing middle and high schools in low-income and minority communities may increase helmet use (Sullins et al., 2014). Similarly, the American Academy of Pediatrics advocates that counseling should be "appropriate for the child's locale" (Gardner \& the Committee on Injury, Violence, and

${ }^{1} J o h n s$ Hopkins University School of Medicine, Baltimore, $M D$, USA

${ }^{2}$ Johns Hopkins Hospital, Baltimore, MD, USA

${ }^{3}$ Johns Hopkins Bloomberg School of Public Health, Baltimore, $M D, U S A$

Authors' Note: We appreciate the support of Ms. Kisha Price for serving as safety educator and collecting research data from pilot test participants, and the youth and their families that participated in this study. This work was presented at the 2018 Pediatric Academic Societies' Annual Meeting. This research was supported by the Thomas Wilson Foundation in Baltimore, Maryland, and the Pediatric Trauma Program at the Johns Hopkins Children's Center. Address correspondence to Leticia Manning Ryan, Department of Pediatrics, Johns Hopkins University School of Medicine, The Charlotte R. Bloomberg Children's Center, 1800 Orleans Street, G-1517, Baltimore, MD 21287, USA; e-mail: Iryan17@jhmi.edu 
Poison Prevention, 2007). Our review of publically available educational videos for youth show that existing resources lack diversity in their participants, do not reflect urban settings, and tend to focus on the mechanics of proper helmet use rather than convincing youth to use helmets.

\section{DESCRIPTION OF THE INNOVATION}

Our goal was to create a culturally tailored educational video that promotes bicycle helmet use for urban children. To inform the video development, we conducted focus groups at a large primary care clinic in an urban academic pediatric hospital in Baltimore, Maryland, where patients are predominantly African American, and almost $90 \%$ are insured through Medicaid or the Maryland Children's Health Insurance Program. The study was approved by the university's institutional review board.

We recruited youth who responded to flyers distributed in the primary care clinic to participate in focus groups to discuss perceptions of barriers and facilitators to helmet use and to solicit their preferences for an educational video. Eligible youth were between 8 and 15 years of age, reported riding a bicycle within the past 6 months, and were able to understand and speak in English, given that the sessions were conducted in English. Youth assent and parent/guardian consent were obtained and an incentive of $\$ 20$ in gift cards and food/drinks was provided.

Participants completed a brief intake survey that included questions on demographics and helmet use. Participants then watched an existing video (the 9-minute-long 2002 U.S. Department of Transportation video, Ride Smart, It's Time to Start) and were asked to identify any strengths and weaknesses and suggest approaches that would be effective in persuading them and their peers to wear helmets. Focus groups were conducted by an experienced moderator using a focus group guide developed by the study team and were audio-recorded; members of the research team and the video producer observed the sessions. The recordings were transcribed and qualitatively analyzed using immersion/crystallization technique by the study team (Miller, 1994). After this, the research team met again to further discuss the analysis. A data summary sheet was created for each session, and these findings were used to clarify important themes and desired images for inclusion in the video. After reviewing summary data, the video producer and one of the authors (EM) drafted a script and storyboards to share with the team for feedback. After several iterations, video shoots were scheduled with students from two local urban schools participating in the production.

\section{INTENDED IMPACT/OUTCOMES}

\section{Focus Groups}

Two focus groups were completed in November 2016 with 6 participants in an 8- to 11-year-old group and 5 participants in a 12- to 15 -year-old group. Overall, 7 of $11(64 \%)$ participants were male and 7 owned $(64 \%)$ a helmet. Among the youth who owned a helmet, 2 of 7 (29\%) used a helmet "all the time." Key emerging themes that informed the video development are summarized in Table 1.

Two major themes included that youth were responsible for keeping themselves safe and described themselves as skilled bike riders who could avoid falls. We also observed that youth began fidgeting about 3 to 4 minutes into the 9-minute video, brought their cell phones to the session, and all the cell phones had cases.

\section{Video Creation}

These themes and observations informed the development of a 4-minute video that linked the concept of use of cases to protect phones to use of bike helmets to protect heads/brains. This video, You Make the Call, included youth from two local public charter schools and can be viewed here http://bit.ly/2Kr7UCN. The title reflects the intent for the video to empower the youth to make the decision to wear a helmet rather than being told to do so.

\section{CHALLENGES AND SUCCESSES}

Our approach to develop a culturally tailored educational video on bike helmet safety has several challenges. First, the use of a single geographical site, the small sample size, and exclusion of non-English speakers may limit generalizability. Second, challenges specifically related to the conduct of focus groups include peer influence on how participants responded and selection bias in the participants themselves. However, we found soliciting information from urban youth to be helpful. Participating youth offered input and strategies to promote helmet use among their peers and helped us to tailor our message to focus on the rationale and need to wear a helmet, rather than the mechanics of proper helmet use. Observations during the sessions contributed to decisions on length of video (4 minutes or less given fidgeting) and content (gave us the idea to link the concept of cases to protect phones to helmets to protect brains). Additionally, focus group themes confirmed several ongoing barriers to helmet use that have been previously reported in the literature, including helmet 
TABLE 1

Focus Group Discussion Themes

\begin{tabular}{|c|c|c|}
\hline Themes From the Focus Group & Quotes From the Children & Ideas for the Storyboard \\
\hline $\begin{array}{l}\text { Youth have an excessive focus on the } \\
\text { individual }\end{array}$ & $\begin{array}{l}\text { - "I’ve been riding since I was } 4 \text {. .." } \\
\text { - "I’m good at riding” } \\
\text { - "You gotta be careful” } \\
\text { - “. . . just look at your surroundings" }\end{array}$ & $\begin{array}{l}\text { Youth need guidance and support } \\
\text { while learning to make their } \\
\text { own decisions. }\end{array}$ \\
\hline $\begin{array}{l}\text { Youth are concerned about style and } \\
\text { comfort }\end{array}$ & $\begin{array}{l}\text { - "The helmet should have more } \\
\text { creativity" } \\
\text { - “. . . it hurts [my head]" } \\
\text { - “. . . it don't feel right" } \\
\text { - “. . . it be making my head sweat" }\end{array}$ & $\begin{array}{l}\text { Comfortable helmets come in a } \\
\text { variety of styles. }\end{array}$ \\
\hline $\begin{array}{l}\text { Youth harbor a sense of invulnerability } \\
\text { despite their experience (egocentric } \\
\text { stage of psychological development) }\end{array}$ & • "I'm safe without it" & $\begin{array}{l}\text { Head trauma could happen to } \\
\text { anyone, regardless of their } \\
\text { cycling experience or ability. }\end{array}$ \\
\hline $\begin{array}{l}\text { Youth thought that a diversity of } \\
\text { voices and role models would be } \\
\text { important for a new video. Kids lack } \\
\text { helmet wearing role models. }\end{array}$ & $\begin{array}{l}\text { - “. . . it should be parents, teachers, } \\
\text { doctors, students, then ambulance” } \\
\text { • “. . . adults, older siblings . . .” } \\
\text { • “. . . my brother doesn’t use one” }\end{array}$ & $\begin{array}{l}\text { Adults want their kids to make } \\
\text { the right decision and wear a } \\
\text { helmet for every ride. }\end{array}$ \\
\hline $\begin{array}{l}\text { Youth recognized that the setting of } \\
\text { the NHTSA video differed from the } \\
\text { setting of their lived experience. }\end{array}$ & • “. . . we should have more streets” & City scenery \\
\hline $\begin{array}{l}\text { Youth had trouble sitting still for the } \\
\text { whole 9-minute video. }\end{array}$ & & Short video message \\
\hline Most youth have phones with cases. & & Phone-case, head-case analogy \\
\hline
\end{tabular}

NOTE: NHTSA = National Highway Traffic Safety Administration.

appearance and comfort, lack of peer use and lack of parent use or endorsement.

\section{NEXT STEPS}

We plan to evaluate the effectiveness of this video in a pilot study. We hypothesize that this culturally tailored video will improve knowledge of bicycle helmet safety, intention to wear a helmet and actual use of bicycle helmets among at-risk urban children.

\section{IMPLICATIONS FOR PRACTICE}

Soliciting information from urban youth with focus groups was helpful for developing this bike helmet promotion video. This youth-informed and culturally tailored approach could be explored as a strategy to address other injury topics in pediatric primary care.

\section{REFERENCES}

Gardner, H. G., \& The Committee on Injury, Violence, and Poison Prevention. (2007). Office-based counseling for unintentional injury prevention. Pediatrics, 119, 202-206.

Miller, W. (1994). Qualitative analysis: How to begin making sense. Family Practice Research Journal, 14, 289-297.

Sullins, V. F., Yaghoubian, A., Nguyen, J., Kaji, A. H., \& Lee, S. L. (2014). Racial/ethnic and socioeconomic disparities in the use of helmets in children involved in bicycle accidents. Journal of Pediatric Surgery, 49, 1000-1003.

Thompson, D. C., Rivara, F. P., \& Thompson, R. S. (1999). Helmets for preventing head and facial injuries in bicyclists (review). Cochrane Database Systematic Reviews, 2000, CD001855.

U.S. Department of Transportation National Highway Traffic Safety Administration. (2013). Traffic safety facts, 2011 databicyclists and other cyclists (DOT HS 811 743). Washington, DC: Author. 